https://doi.org/10.52676/1729-7885-2021-4-10-15

УДК: 533.9.03, 533.9.082

\title{
RESULTS OF SPECTROSCOPIC MEASUREMENTS OF PLASMA DISCHARGES AT THE KTM TOKAMAK
}

\author{
S.A. Zhunisbek, B.Zh. Chektybaev, A.D. Sadykov, A.A. Zhaksybaeva, K. Zhenis, A.N. Madiyanova \\ Branch "Institute of Atomic Energy" RSE NNC RK, Kurchatov, Kazakhstan \\ E-mail for contacts: zhunisbek@nnc.kz
}

The paper presents the results of spectroscopic measurements of plasma discharges at the KTM tokamak. The measurements were carried out during the June 2021 campaign, which plasma discharges were obtained with a plasma current from $120 \mathrm{kA}$ to $150 \mathrm{kA}$ and a duration of $\sim 250 \mathrm{~ms}$.

In connection with the design changes inside the vacuum chamber of the tokamak, special attention is paid to the study of the elemental composition of the plasma and the analysis of impurities and the ways of their entry is carried out. Impurities in plasma directly affect radiation losses. Optical spectroscopy (OS) is one of the main methods for studying the penetration of impurities into plasma.

An Avaspec-ULS2048CL-EVO-RS-BB spectrometer was used to determine the emission spectrum of the KTM tokamak plasma. The time evolution of the hydrogen lines was measured using the diagnostics of a $\mathrm{H} \alpha-\mathrm{D} \alpha$ monitor equipped with narrow-band interference filters (FWHM $1 \mathrm{~nm}$ ).

Based on the measured emission spectrum, it was found that in the hydrogen plasma of the KTM tokamak, in addition to the presence of a working gas, there were also impurities of carbon, oxygen, nitrogen and argon (C, O, N, Ar) in various ionization states.

Keywords: KTM tokamak, plasma, optical diagnostics, spectroscopy, spectral lines.

\section{INTRODUCTION}

In November 2019, the final stage of the physical start-up was implemented at the KTM tokamak [1], which demonstrated the operability of the facility and its main technological systems. During the experimental campaign, plasma discharges with plasma currents up to $100 \mathrm{kA}$ and durations of $65 \mathrm{~ms}$ were obtained at the KTM Tokamak. To increase the parameters of plasma discharges, the vacuum chamber (VC) of the KTM tokamak was covered with graphite tiles.

An important role in studies of plasma physics and plasma-wall interaction is played by plasma emission measurements in the visible spectrum range. Such diagnostics include $\mathrm{H} \alpha-\mathrm{D} \alpha$ hydrogen line emission monitor, survey spectrometer, video observation system, etc. The above-mentioned diagnostics are basic and are used in practically all facilities with magnetic plasma confinement. The performance of the above-mentioned diagnostics and the quality of the data they provide determines the performance of the facility and the quality of the investigations performed. For example, the level and dynamics of hydrogen lines emission can be used to judge about achieving the plasma discharge and hydrogen recycling mode on the first wall of the tokamak VC [2]. The elemental composition of the plasma and the amount of impurities in it can be determined from the survey spectrometer diagnostics [3]. The system of highspeed video observation allows observations of the process of plasma formation and development, the process of plasma-wall interaction, to study and monitor different kinds of turbulences, MHD instabilities and disruptions.
The present work shows results of spectroscopy measurements of visible and near-infrared (360-900 nm) plasma radiation from the KTM tokamak.

\section{EQUIPMENT AND SCHEME OF MEASUREMENT}

The $\mathrm{H} \alpha-\mathrm{D} \alpha$ monitor diagnostic is used to observe the time evolution of the emission intensity of $\mathrm{H \alpha} 656.3 \mathrm{~nm}$ hydrogen lines. During the June 2021 campaign, an upgraded $\mathrm{H} \alpha$-D $\alpha$ monitor diagnostic was used. In upgrading the diagnostics of $\mathrm{H} \alpha$-D $\alpha$ monitor, the optical unit and the receiving and transmitting path of the diagnostics have been modified. The optical unit is based on a single collecting lens and an interference filter with a bandwidth of $1 \mathrm{~nm}$, the receiving and transmitting path includes a collimating lens and a 10-meter fibre optic cable. Figure 1 shows the schematic diagram and general view of $\mathrm{H} \alpha$-D $\alpha$ monitor.

Diagnostics of $\mathrm{H} \alpha-\mathrm{D} \alpha$ monitor consists from three main parts:

- input objective lens and fiber optic cable that collects light from the installation and transmits it to the optical diagnostics unit;

- optical block, that transmits $\mathrm{H} \alpha$ lines emission $(656.3 \mathrm{~nm})$;

- radiation detector (PMT) designed to detect the emission of $\mathrm{H} \alpha$ lines $(656.3 \mathrm{~nm})$.

Avaspec-ULS2048CL-EVO-RS fiber optic spectrometer from Avantes is used to record the most intense spectral lines. The spectrometer is based on a CMOS linear image sensor and a BB diffraction grating of $600 \mathrm{ln} / \mathrm{mm}$. The main technical specifications of the spectrometer are given in the table below 1 . 


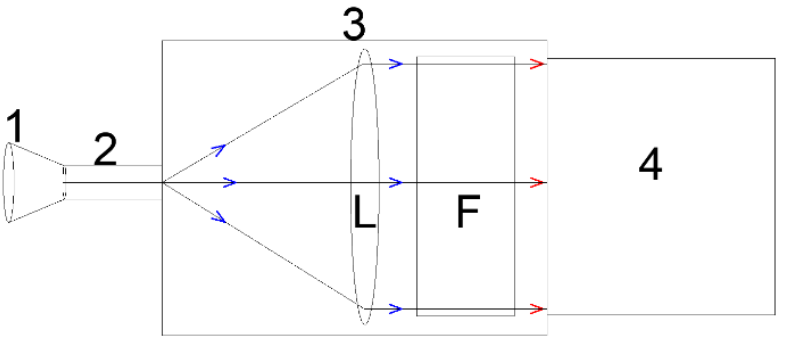

1 - collimating lens; 2 - 10-meter fiber optic cable; 3 - optical block ( $\mathrm{L}$ - collecting lens, $\mathrm{F}$ - interference filter); 4 - photomultiplier tube (PMT)

a) Basic Scheme

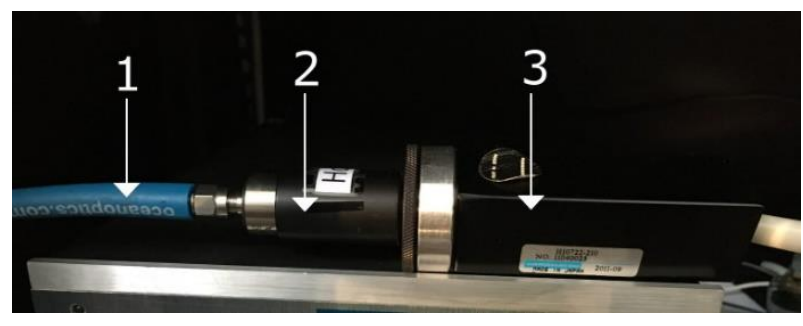

1 - Fiber optic cable; 2 - optical block;

3 - photomultiplier tube H10722-210 (PMT)

b) General View of Diagnostics

Figure 1. Diagnostics of the hydrogen emission intensity monitor

Table 1. Basic Technical Specifications of Spectrometer

\begin{tabular}{|l|c|}
\hline Optical bench & Symmetric Czerny-Turner \\
\hline Detector & CMOS line, 2048 elements $(14 \times 200 \mu \mathrm{m})$ \\
\hline Operating range & $360-880 \mathrm{~nm}$ \\
\hline Optical resolution & $0,6-0,7 \mathrm{~nm}$ \\
\hline Sensitivity & 375000 counts $/ \mu \mathrm{W}$ for the integration time \\
\hline Integration time & $9 \mu \mathrm{s}-59 \mathrm{~s}$ \\
\hline Input slit & $25 \mu \mathrm{m}$ \\
\hline
\end{tabular}

High-speed video surveillance system [4] based on a Fastec Inline camera with a maximum rate of $1000 \mathrm{fps}$ at a resolution of $320 \times 240$ is used to monitor visually the formation and development of plasma thread.

In order to increase the field of observation, the system of collecting light diagnostics of the survey spectrometer and the monitor $\mathrm{H} \alpha-\mathrm{D} \alpha$ are installed on the track branch of the 10th sector of the VC of tokamak KTM. The location of the light collection system components at the $\mathrm{VC}$ of tokamak KTM is shown in Figure 2.

The optical diagnostics light acquisition and image transmission systems consist of collimating lenses F110SMA-633 with $\sim 45^{\circ}$ viewing angle and FC-600VIS fiber optic cables with $600 \mu \mathrm{m}$ core diameter. The length of fiber optic cables is $5-10 \mathrm{~m}$ that allows diagnostics with a recording system to be located at a safe distance from the installation, creating conditions for high interference immunity of the equipment against electromagnetic interference and ionising radiation.

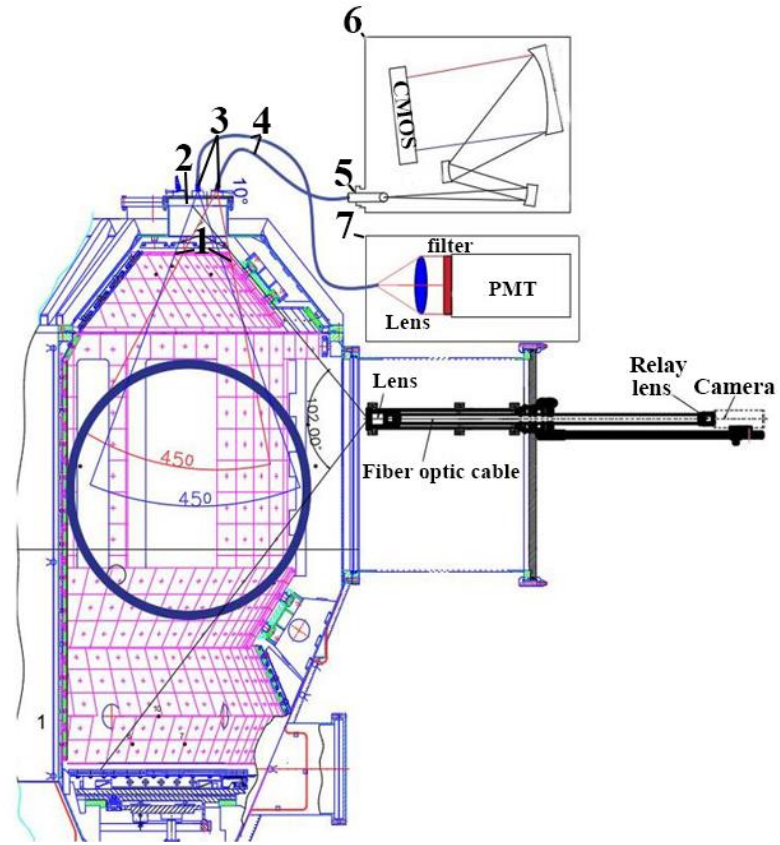

1 - field of view of lenses; 2 - quartz window; 3 - collimating lens; 4 - fiber optic cable; 5 - entrance slit; 6 - spectrometer Avaspec; 7 - diagnostics of monitor $\mathrm{Ha}-\mathrm{Da}$

Figure 2. Measurement Scheme at KTM tokamak

\section{RESULTS AND DISCUSSIONS}

During the experimental campaigns, plasma radiation was measured in the range of $360-900 \mathrm{~nm}$. As an example, measurements in a series of repeated plasma discharges \#4396-4398 in ohmic heating mode are shown. Figure 3 shows the main parameters of plasma discharges and measurement results.

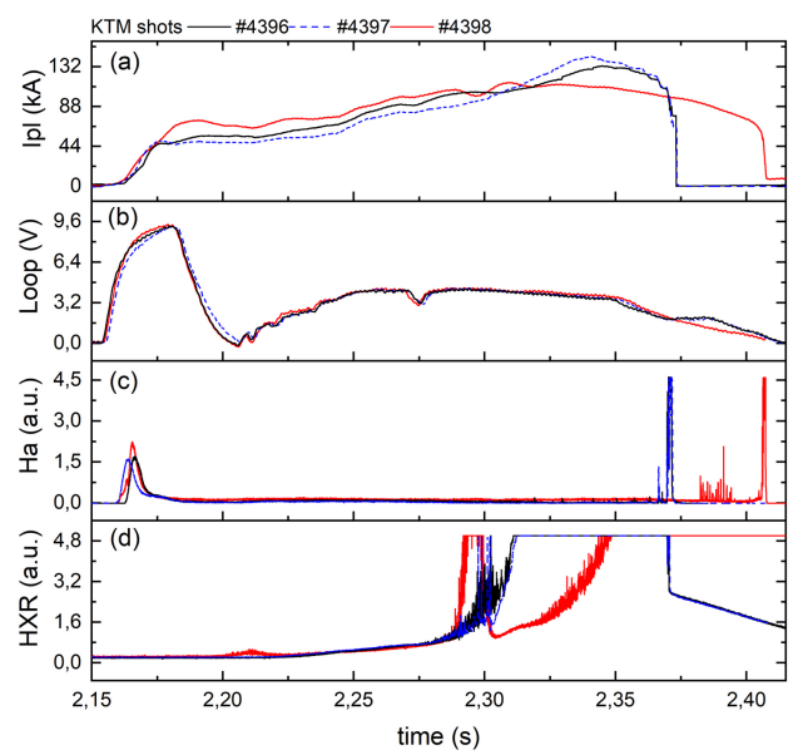

Figure 3. Temporal evolution of main parameters of plasma discharges: (a) plasma current; (b) bypass voltage; $(c)$ intensity of emission of $H \alpha$ lines; (d) intensity of hard X-rays 
Figure 3 shows the value of the plasma current, loop voltage, intensity of the luminescence of the $\mathrm{H} \alpha$ lines, and the data from HXR (Hard X-ray Rays) diagnostics for discharges \#4396-4398. As it is seen from Figure 3, the maximum achieved plasma current was about $150 \mathrm{kA}$. The loop voltage on internal bypass of $\mathrm{VC}$ during the working gas breakdown $(2.16-2.20 \mathrm{sec}$.) was about $\sim 6 \mathrm{~V}$.

The monitor of hydrogen line emission intensity recorded an increase in the luminous intensity of the $\mathrm{H} \alpha$ lines during the first $10 \mathrm{~ms}$ due to hydrogen breakdown. After the breakdown at the stage of plasma current growth, the H $\alpha$ luminous level drops, indicating complete ionization of the working gas. In the stable phase of discharge (2190-2360 ms) no bright bursts of $\mathrm{H} \alpha$ glow were observed. Increase of $\mathrm{H} \alpha$ glow was observed at plasma attenuation, which is connected with recharge (recombination) of working gas.

At the higher discharge parameters, the presence of hard X-ray emission was regularly observed. According to HXR diagnostics the level of hard X-ray emission starts to increase closer to the end of the discharge
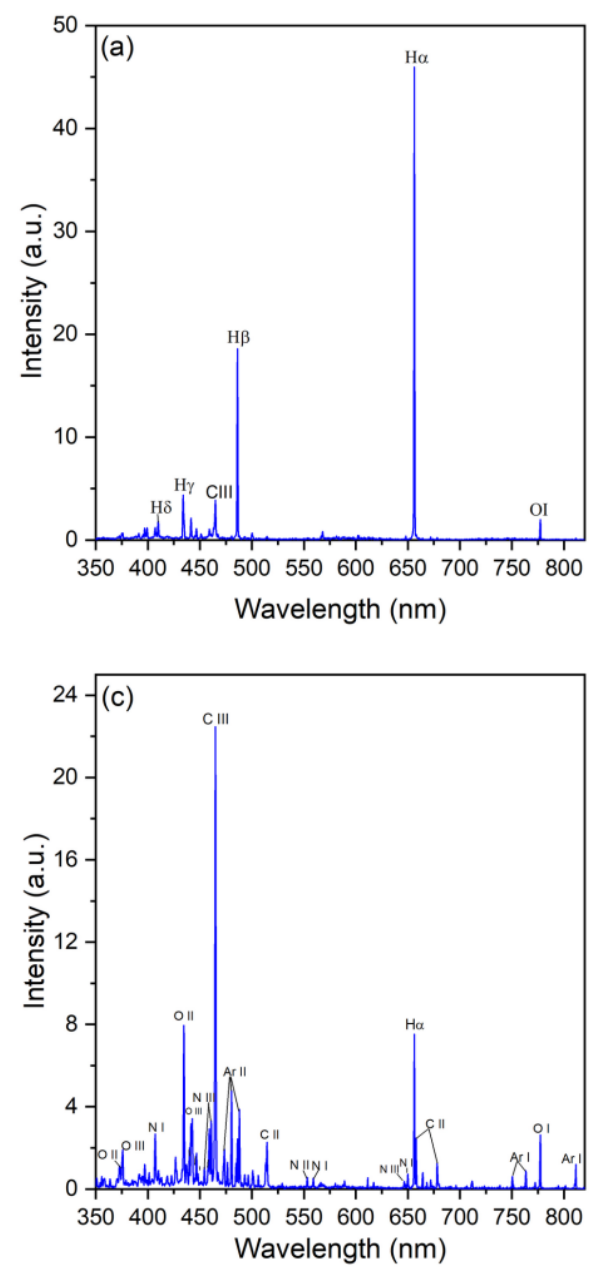

starting from the moment of $2300 \mathrm{~ms}$. It seems to be caused by formation of beams of accelerated electrons, that periodically emerge on the chamber wall with increasing plasma current and cross section of the cord during the considered time interval. At the same time during the campaign, the inlet of hydrogen working gas into VC was carried out in a constant static mode without changing its flow during the whole discharge. Thus, at increase of plasma cord cross-section there is decrease of plasma density that promotes generation of beams of accelerated electrons.

The intense glow of hard X-ray radiation after the plasma current decays is due to the fact that afterglow is observed after long-term emission of the natrium iodine scintillator.

Figure 4 shows the emission spectra of hydrogen plasma of KTM tokamak in the wavelength range of $360-820 \mathrm{~nm}$. The main characteristic lines for hydrogen plasma are $\mathrm{H} \alpha \quad(656.3 \mathrm{~nm}), \mathrm{H} \beta \quad(486.14 \mathrm{~nm}), \mathrm{H} \gamma$ $(434.05 \mathrm{~nm})$ and $\mathrm{H} \delta(410.18 \mathrm{~nm})$. From the spectra registered, besides the working gas lines, the impurity lines $(\mathrm{C}, \mathrm{O}, \mathrm{N}, \mathrm{Ar})$ can be observed.
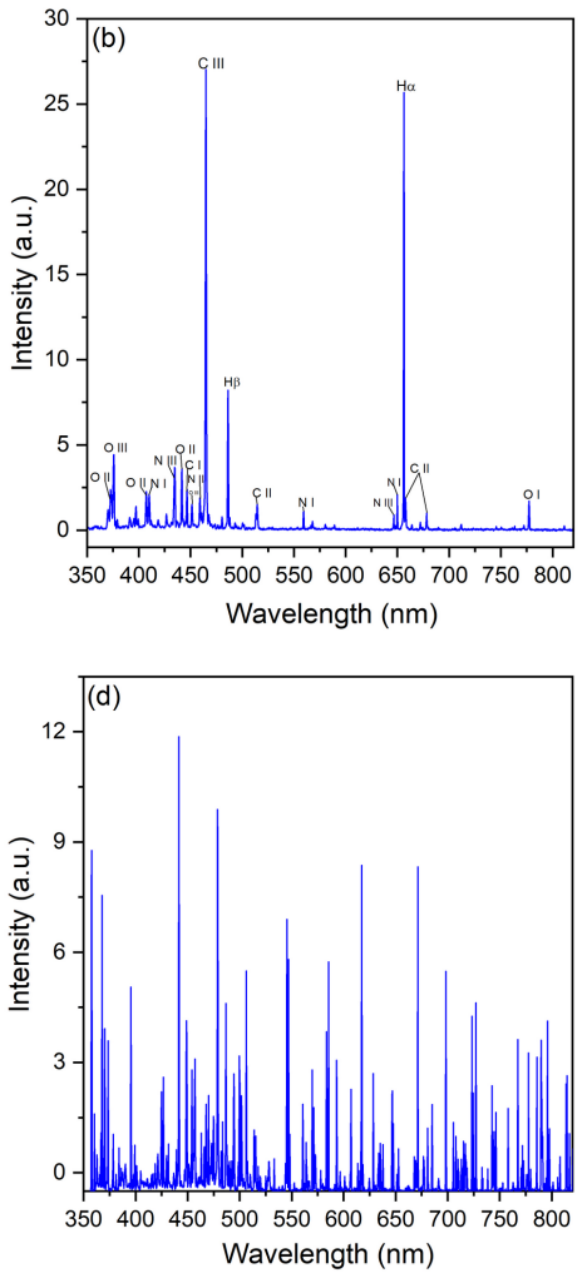

Figure 4. Plasma emission spectrum of KTM tokamak: (a) during breakdown (2160-2170 ms); (b) after breakdown (2170-2180 ms); (c) at plasma current growth stage (2210-2220 ms); (d) at the end of discharge (2290-2370 ms) 


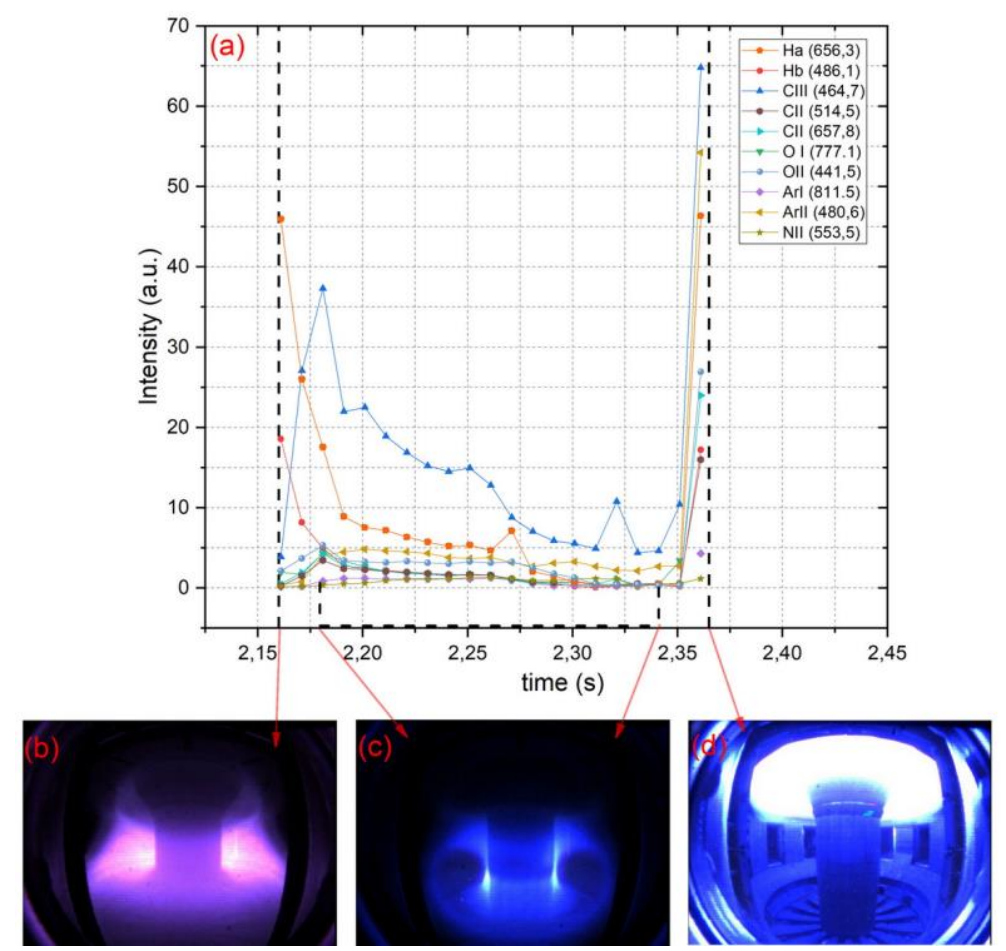

Figure 5. Evolution of spectral lines glow intensity (a) and video shots made during breakdown (b), at plasma current growth stage (c) and at the end of the discharge (d)

As is seen from the Figure 4, hydrogen spectral lines of Balmer series prevails during breakdown $(\mathrm{H} \alpha, \mathrm{H} \beta, \mathrm{H} \gamma$, $\mathrm{H} \delta$ ). After breakdown the intensity of Balmer lines emission reduces by half, that gives evidence on the working gas ionization (see Figure 4, b). Starting from $2170 \mathrm{~ms}$ the impurity lines glow is observed such as oxygen (O I, O II, O III), carbon (C I, C II, C III) and nitrogen (N I, N II, N III). Argon spectral lines (Ar I, Ar II) appear in spectrum at plasma current growth stage (see Figure 4,c). During plasma attenuation from $2290 \mathrm{~ms}$, spectrometer starts to register lines (see Figure 4, d) not typical for these elements. Such effect is most likely associated with close location of spectral equipment to VC of KTM tokamak and electro-magnetic waves, caused by plasma, such as hard X-rays, influencing on electronic parts of spectrometer. These factors cause the instrument not to work properly displaying incorrect spectrum. Accordingly, spectral equipment is supposed to be shielded with lead plates during further experimental start-ups.

Figure 5 presents the dynamic of glow intensity change for brighter spectral lines $(\mathrm{H} \alpha 656.28 \mathrm{~nm}, \mathrm{H} \beta$ $486.1 \mathrm{~nm}$, C III $464.7 \mathrm{~nm}$, C II $657.8 \mathrm{~nm}$, C II $5145 \mathrm{~nm}$, O I $777.1 \mathrm{~nm}$, O II $441.5 \mathrm{~nm}$, Ar I $811.5 \mathrm{~nm}$, Ar II $480.6 \mathrm{~nm}, \mathrm{~N}$ II $553.5 \mathrm{~nm}$ ) and video images from fast camera.

It is clearly seen in the Figure 5, that the main impurity element in tokamak plasma is twice ionized carbon C III $(464.7 \mathrm{~nm})$. Bright burst of C III lines (464.7 $\mathrm{nm}$ ) was observed after breakdown during plasma thread boundary increase.
Then, the intensity of C III lines glow (464.7 nm) varied within 18-10 conventional units. The glow of dominant dark-blue color on the plasma boundary corresponds well with spectral measurements. At the moment of registration, the exposure of fast camera composed about $4 \mathrm{~ms}$ at the shooting speed of $250 \mathrm{k} / \mathrm{s}$. The video images show the discharge developing near the central solenoid (see Figure 5, b). At the stage of plasma current growth after $2170 \mathrm{~ms}$, the plasma thread begins to press against VC inner wall, then from $2220 \mathrm{~ms}$ the plasma thread separates from inner wall and the next $150 \mathrm{~ms}$ holds the thread-ring shape (see Figure 5, c).

Table 2 presents the main reasons of registered impurities presence in KTM tokamak plasma.

Table 2. Main reasons of impurities presence in KTM tokamak plasma

\begin{tabular}{|c|l|}
\hline $\mathbf{N}, \mathbf{0}$ & $\begin{array}{l}\text { 1. Oxygen and nitrogen are the main air components and their } \\
\text { availability is associated with their escape from the chamber walls } \\
\text { as a residual gas. } \\
\text { 2. Oxygen may occur due to dissociation of water and other } \\
\text { oxides molecules, adsorbed on vacuum chamber walls. } \\
\text { 3. Also, additional intake of the mentioned gases is not exclu- } \\
\text { ded due to leaking from the atmosphere through microleakage } \\
\text { in VC structure elements. }\end{array}$ \\
\hline Ar & $\begin{array}{l}\text { Technological regimes of KTM VC cleaning at night is one of the } \\
\text { reasons of Ar lines appearance on line spectra. During VC pre- } \\
\text { paration for operational modes, high vacuum pumping and VC } \\
\text { degasification are carried out with periodical baking of chamber } \\
\text { walls and their cleaning with glow discharge. Argon was used as } \\
\text { gas in glow discharge. Argon refers to heavy elements that are } \\
\text { hard to pump out from working chamber. }\end{array}$ \\
\hline $\mathbf{C}$ & $\begin{array}{l}\text { The source of such impurity ingress are graphite tiles, that cover } \\
\text { practically the whole inner surface of vacuum chamber, resulting } \\
\text { in carbon intake under plasma influence. }\end{array}$ \\
\hline
\end{tabular}


Registered lines were identified using reference tables [5,6], on the assumption of which types of impurities are possible, for instance, from mass-spectrometric analysis and intrachamber lining composition. However, the correct identification of specific emission line is rather complicated. Firstly, the line relative intensity depends on both density and temperature of the colliding particles. Moreover, within the range of waves length of the spectrometer used there are many emission lines with different ionization degree, and within its resolution capability it is usually possible to identify several potential emitting elements for a particular emission line.

Comparison with emission spectra, measured at other tokamaks (T-10 [3], COMPASS [7]), shows the coincidence of the main spectral lines observed. These spectral lines were taken from the National Institute of Standards and Technology (NIST) database [8]. Studying data on KTM tokamak plasma emission spectrum, the following conclusions can be made:

1. Peaks of $\mathrm{H} \alpha$ lines are observed at the beginning of the discharge, due to hydrogen ionization and at the end of the discharge due to plasma-wall interaction and at the end of the discharge. $\mathrm{H} \alpha$ lines emission intensity decreases between peaks in the beginning and at the end of the discharge.

2. Line spectrum of tokamak plasma composes of limited quantity of lines (N, O, Ar) and with clearly noticeable lines $\mathrm{H} \alpha$ and C III. Relatively bright carbon lines during discharge formation and maintenance are due to plasma interaction with graphite tiles of the VC inner walls at KTM tokamak. To reduce the entry of carbon impurities it is necessary to optimize the tokamak operating scenario by reducing the plasma interaction with the wall.

3. In the process of measurements, it was found, that under certain conditions the emission intensity of Ar I and Ar II lines rather exceeded the emission of other impurity lines that occurred in plasma. A serious disadvantage while using argon in glow discharges is the difficulty of pumping when reaching the optimum vacuum $\left(5 \cdot 10^{-5}\right.$ Torr $)$ in the discharge chamber. To exclude Ar from plasma composition during VC technological cleaning in glow discharges, lighter gases shall be used such as hydrogen and helium.

4. Noise appearance in the spectrum is associated with instrument exposure by hard x-rays that appear during plasma attenuation.

\section{CONCLUSION}

In the process of 2021 experimental campaign to obtain plasma charge at extended parameters, the measurements were made to obtain plasma in visual and near IR spectrum areas (360-900 nm). Upon results of emission spectra measurements, the plasma impurity composition, sources and mechanisms of their entry were identified. It was found, that in the hydrogen plasma of the KTM tokamak, besides the presence of working gas

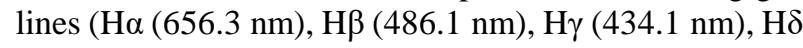

$(410.2 \mathrm{~nm})$ ), there were also impurity lines $(\mathrm{C}, \mathrm{O}, \mathrm{N}, \mathrm{Ar})$ in various ionization states.

Time evolution of $\mathrm{H} \alpha$ lines $(656.3 \mathrm{~nm})$ with $0.005 \mathrm{~ms}$ time resolution showed the increase in $\mathrm{H} \alpha$ lines intensity $(656.3 \mathrm{~nm})$ in the beginning and at the end of the discharge. As expected, no bright bursts of $\mathrm{H} \alpha$ lines were observed in stable phase of the discharge, which indicates the absence of overcharge processes.

The shape and position of plasma thread in the dynamics were identified upon measurements from the video observation system. The working results will be used for further experiments on plasma obtaining and increasing its parameters.

\section{REFERENCES}

1. Study of breakdown and plasma formation in the KTM tokamak with the massive conductive vacuum chamber / B. Chektybayev, A. Sadykov, E. Batyrbekov, M. Skakov, D. Zarva, I. Tazhibayeva, A. Korovikov, Ye. Kashikbayev, D. Olkhovik, V. Savkin, P. Khvostenko, I. Belbas, D. Sergeyev, A. Kavin, A. Lee, V. Pavlov // Fusion Engineering and Design Volume 163, February 2021, 112167.

2. H.K. Na, S. Sajjad, J.M. Park, M. Kwon. Configuration and installation design of optical diagnostic systems on KSTAR. Fusion Engineering and Design. Volume 86 (2011). - P. 66-70.

3. A.V. Gorbunov, L.A. Klyuchnikov, K.V. Korobov. Spektr izlucheniya plazmy tokamaka $\mathrm{T}-10 \mathrm{v}$ vidimom diapazone. VANT. Ser. Termoyadernyy sintez, 2015, T. 38, issue. 2.

4. Visible wide angle view imaging system of KTM tokamak based on multielement image fiber bundle / B. Chektybayev, G. Shapovalov, A. Kolodeshnikov // Review of Scientific Instruments. - May 2015. - Vol. 86, Issue 5. https://doi.org/10.1063/1.4921475.

5. A.N. Zeydel', V.K. Prokof'ev, S.M. Rayskiy, V.A. Slavnyy, E.Ya. Shreyder. Tablitsa spektral'nykh liniy. Moscow, 1977.

6. A.R. Striganov, N.S. Svintitskiy. Tablitsy spektral'nykh liniy neytral'nykh i ionizovannykh atomov. - Moscow, 1966.

7. D. Naydenkova, J. Stöckel, V. Weinzettl, D. Šesták, J. Havlíček. First Spectroscopic Measurements on the COMPASS Tokamak. WDS'09 Proceedings of Contributed Papers, Part II, 158-162, 2009.

8. NIST.AtomicSpectraDatabase.LinesData / (https://physics.nist.gov/PhysRefData/ASD/lines_form.ht $\mathrm{ml})$.

\section{ЛИТЕРАТУРА}

1. Study of breakdown and plasma formation in the KTM tokamak with the massive conductive vacuum chamber / B. Chektybayev, A. Sadykov, E. Batyrbekov, M. Skakov, D. Zarva, I. Tazhibayeva, A. Korovikov, Ye. Kashikbayev, D. Olkhovik, V. Savkin, P. Khvostenko, I. Belbas, D. Sergeyev, A. Kavin, A. Lee, V. Pavlov // Fusion Engineering and Design Volume 163, February 2021, 112167.

2. H.K. Na, S. Sajjad, J.M. Park, M. Kwon. Configuration and installation design of optical diagnostic systems on KSTAR. Fusion Engineering and Design. Volume 86 (2011). - P. 66-70. 
3. А.В. Горбунов, Л.А. Ключников, К.В. Коробов. «Спектр излучения плазмы токамака Т-10 в видимом диапазоне». ВАНТ. Сер. Термоядерный синтез, 2015, т. 38 , вып. 2.

4. Visible wide angle view imaging system of KTM tokamak based on multielement image fiber bundle / B. Chektybayev, G. Shapovalov, A. Kolodeshnikov // Review of Scientific Instruments. - May 2015. - Vol. 86, Issue 5. https://doi.org/10.1063/1.4921475.

5. А.Н. Зейдель, В.К. Прокофьев, С.М. Райский, В.А. Славный, Е.Я. Шрейдер «Таблица спектральных линий». - Москва, 1977 г.
6. А.Р. Стриганов, Н.С. Свинтицкий «Таблицы спектральных линий нейтральных и ионизованных атомов». - Москва, 1966.

7. D. Naydenkova, J. Stöckel, V. Weinzettl, D. Šesták, J. Havlíček. First Spectroscopic Measurements on the COMPASS Tokamak. WDS'09 Proceedings of Contributed Papers, Part II, 158-162, 2009.

8. NIST.AtomicSpectraDatabase.LinesData / (https:// physics.nist.gov/PhysRefData/ASD/lines_form.html).

\title{
КТМ ТОКАМАК ПЛАЗМА РАЗРЯДТАРЫН СПЕКТРОСКОПИЯЛЫҚ ӨЛШЕУДІН НӘТИЖЕЛЕРІ
}

\author{
С.А. Жүнісбек, Б.Ж. Чектыбаев, А.Д. Садыков, А.А. Жаксыбаева, Қ. Женіс, Ә.Н. Мадиянова \\ ҚР ҰЯО РМК «Атом энергиясы институты» филиалы, Курчатов, Қазахстан
}

Мақалада КТМ токамагындағы плазмалық разрядтардың спектроскопиялық өлшеу нәтижелері берілген. Өлшемдер 2021 жылдың маусым айындағы науқан кезінде алынды. Науқан барысында плазмалық разрядтар 120 кА-ден 150 кА-ге дейінгі плазмалық токпен және 250 мс ұзақтығымен алынды.

Бұл жұмыста плазманың элементтік құрамын зерттеуге, қоспаларды талдауға және олардың түсу жолдарын анықтауға ерекше назар аударылады. Плазмадағы қоспалар радиациялық шығындарға тікелей әсер етеді. Оптикалық спектроскопия (ОС) қоспалардың плазмаға түсуін зерттейтін негізгі әдістерінің бірі болып табылады. ҚТМ токамак плазмасының эмиссия спектрін анықтау үшін Avaspec-ULS2048CL-EVO-RS-BB спектрометрі пайдаланылды. Сутегі спектрлік сызығының уақыт эволюциясы тар жолақты интерференционды сүзгілерімен (FWHM 1 нм) жабдықталған H $\alpha$-D $\alpha$ мониторының диагностикасы арқылы өлшенді.

Сәуле шығару спектрі негізінде ҚТМ токамак сутегі плазмасында жұмысшы газдан бөлек көміртегі, оттегі, азот және аргон (C, O, N, Ar) қоспалары да әртүрлі иондану күйінде болатыны анықталды.

Түйін сөздер: ҚТМ токамак, плазма, оптикалық диагностика, спектроскопия, спектрлік сызықтар.

\section{РЕЗУЛЬТАТЫ СПЕКТРОСКОПИЧЕСКИХ ИЗМЕРЕНИЙ ПЛАЗМЕННЫХ РАЗРЯДОВ НА ТОКАМАКЕ КТМ}

\author{
Жүнісбек С.А., Чектыбаев Б.Ж., Садыков А.Д., Жаксыбаева А.А., Женіс Қ., Мадиянова Ә.Н. \\ Филиал «Институт атомной энергии» РГП НЯЦ РК, Курчатов, Казахстан
}

В работе приведены результаты спектроскопических измерений плазменных разрядов на токамаке КТМ. Измерения проводились во время июньской кампании 2021 года, в ходе которой были получены плазменные разряды с током плазмы от 120 кА до 150 кА и длительностью 250 мс.

В работе особое внимание уделено изучению элементного состава плазмы и проводится анализ примесей и путей их поступления. Примеси в плазме напрямую влияют на радиационные потери. Оптическая спектроскопия (ОС) является одним из основных методов исследования поступления примесей в плазму.

Для определения спектра излучения плазмы токамака КТМ использовался спектрометр Avaspec-ULS2048CLEVO-RS-BB. Временная эволюция линий водорода измерялась с помощью диагностики монитора Н $\alpha$-D $\alpha$, снабженной узкополосными интерференционными фильтрами (FWHM 1 нм).

По измеренному спектру излучения было обнаружено, что в водородной плазме токамака КТМ кроме наличия рабочего газа, также имелись примеси углерода, кислорода, азота и аргона (C, O, N, Ar) в различных ионизационных состояниях.

Ключевые слова: токамак КТМ, плазма, оптические диагностики, спектроскопия, спектральные линии. 